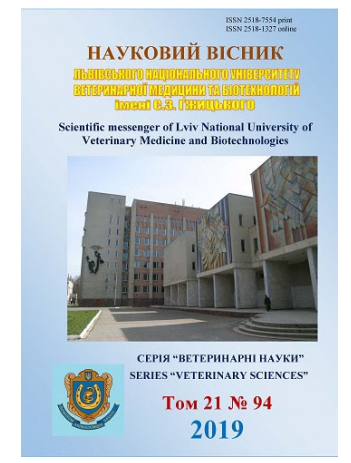

\author{
Науковий вісник Дьвівського національного університету \\ ветеринарної медицини та біотехнологій імені С.З. Гжицького. \\ Серія: Ветеринарні науки \\ Scientific Messenger of Lviv National University \\ of Veterinary Medicine and Biotechnologies. \\ Series: Veterinary sciences
}

\title{
Application of aflubine in the treatment scheme for pigs with respiratory syndrome
}

\author{
Zh.V. Rybachuk, O.Ye. Galatyuk, T.O. Romanyshyna \\ Zhytomyr National Agroecological University, Zhytomyr, Ukraine
}

Article info

Received 10.04.2019

Received in revised form 10.05 .2019

Accepted 13.05.2019

Zhytomyr National Agroecological University, Korolyova Str., 39. Zhytomyr, 10025, Ukraine. Tel. $+38-097-564-78-34$

E-mail: zhrybachuk@ukt.net
Rybachuk, Zh.V., Galatyuk, O.Ye., \& Romanyshyna, T.O. (2019). Application of aflubine in the treatment scheme for pigs with respiratory syndrome. Scientific Messenger of Lviv National University of Veterinary Medicine and Biotechnologies. Series: Veterinary sciences, 21(94), 86-91. doi: $10.32718 /$ nvlvet 9416

The article investigates into changes of clinical parameters and leukograms of pigs with respiratory syndrome in comparison with the use of unprotected antibiotics penicillins (amoxicillin suspension 15\%), third generation cephalosporins (ceftracone) and complex therapy (ceftracone in combination with oral administration of aflubin). In pigs, many pathogens (bacteria and viruses) parasitize, which can affect the upper respiratory tract. Failure to observe the rules for the use of antibiotics for the treatment of animals leads to the formation of resistant forms of microorganisms. Therefore, the introduction of treatment regimens that simultaneously have a polyvectoral action and stimulate the functioning of the body systems (as well as the work of homeopathy), allows you to achieve a positive therapeutic effect more quickly. In a private household where pigs are kept fattened, the disease of pigs with respiratory syndrome is registered, mostly in 14-28 days after purchase. In such animals, body temperature increased to 41.0-41.1 degrees Celsius, fever, weakness, lack of appetite, animals buried in the litter, and in the leukoformula, a slight increase (by $4.8 \%$ excess of the upper physiological limit) of lymphocytes and a slight decrease in segmental nuclei neutrophils (by a maximum 1.2\% below the minimum physiological level). From pigs with respiratory syndrome, on the principle of analogues, formed three groups of 4 animals. For treatment, the first group used emulsion amoxicillin $15 \%$ from the rate of $1 \mathrm{~cm}^{3} / 10 \mathrm{~kg}$ of body weight of the animal, the second ceftriaxone $(20 \mathrm{mg} / \mathrm{kg}$ body weight 2 times a day for 3-5 days), the third - with ceftriaxone aflubin at the expense 10 drops $\left(0.5 \mathrm{~cm}^{3} / 60 \mathrm{~kg}\right.$ body weight for 3 days). Pigs eagerly consumed the drug when we took the drug into the syringe and orally, inserting the cannula for the lower lip. Based on randomized controlled trials, the simultaneous use of ceftriaxone intramuscularly and oral administration of Aflubine every 4 hours (during the first day), and subsequently with an interval of 12 hours for 3 days, contributes to complete clinical healing within the first day after commencing the use of drugs and shortens the treatment period pigs in 2 times, than the introduction of only ceftraxone. Oral use of aflubin in pigs administered intramuscularly amoxicillin provided cure for the next 12 hours, manifested by the restoration of appetite. Consequently, administration of aflubine with ceftriaxone and amoxicillin provides a reduction in the duration of pigs' treatment with respiratory syndrome, which will reduce the use of antibiotics. Therefore, we consider it expedient to introduce into the schemes of this homeopathic remedy treatment in the therapy of pigs with symptoms of the infectious etiology respiratory system.

Key words: aflubin, ceftriaxone, amoxicillin, pigs, respiratory diseases, treatment.

\section{Застосування афлубіну в схемі лікування свиней з респіраторним синдромом}

\author{
Ж.В. Рибачук, О.Є. Галатюк, Т.О. Романишина
}

Житомирський національний агроекологічний університет, м. Житомир, Украӥна 
Вивчено зміну клінічних показників та лейкограми свиней із респіраторним синдромом. При иььому у трьох групах свиней проводилось вивчення порівняльного лікування: пеніциліном (суспензія амоксициліну 15\%); цефалоспорином третього покоління (цефтріаксон); иефтріаксоном у поєднанні з пероральним введенням афлубіну. У приватному господарстві, де утримуються свині на відгодівлі, зареєстровано захворювання свиней із респіраторним синдромом, який клінічно проявлявся через 14-21 добу після закупівлі. У таких тварин реєстрували підвищення температури тіла до 41,0-41,1 ${ }^{\circ}$ С, кволість, малорухливість, відсутність апетиту, тварини заривались у підстилку, кількість лейкочитів була меншою за нижню фізіологічну межу (6,5 \pm 0,3 Г/л), а у лейкоформулі виявляли незначне збільшення на 4,8\% лімфочитів порівняно з фізіологічною нормою та незначне зменшення сегмендоядерних нейтрофілів на 2-3\% порівняно з фізіологічної нормою. 3 хворих свиней із респіраторним синдромом за принципом аналогів сформовано три групи по 4 тварини. Для проведення лікування першій групі використовували емульсію амоксициліну 15\% із розрахунку 1 см $^{3} / 10$ кг маси тіла тварини, другій - цефтріаксон (20 мг/кг маси тіла 2 рази на добу протягом 3-5 діб), третій - разом із иефтріаксоном афлубін із розрахунку 10 крапель (0,5 см³/60 кг маси тіла тварини протягом 3 діб). Свині охоче спожсивали афлубін, коли ми препарат набирали у шприц і задавали перорально, вставивщи канюлю за нижню губу. Нами було встановлено, цио одночасне використання внутрішньом'язево цефтріаксону та пероральне введенням препарату афлубін кожні 4 години (впродовж першої доби), а надалі з інтервалом 12 год протягом 3 діб сприяє повному клінічному одужанню протягом другої доби після початку застосування препаратів та скорочувало термін лікування свиней у 2 рази, порівняно з введенням лише иефтріаксону. Пероральне використання афлубіну свиням, яким вводили внутрішньом'язово амоксицилін, забезпечило одужання в наступні 12 годин, щзо проявлялось відновленням апетиту. Отже, введення афлубіну разом із цефтріаксоном забезпечує скорочення терміну лікування свиней із респіраторним синдромом, що сприятиме зменшенню використання антибіотиків. Тому вважаємо за доцільне введення у схеми лікування даного гомеопатичного засобу при проведенні терапії свиней із респіраторним синдромом.

Ключові слова: афлубін, цеефтріаксон, амоксицилін, свині, респіраторний синдром, лікування.

\section{Ветуп}

У свиней персистує багато патогенних збудників (бактерій та вірусів), які можуть вражати верхні дихальні шляхи. При продажі-купівлі поросят у відгодівельні господарства як продавці так і покупці не завжди дотримуються виконання спеціальних ветеринарносанітарних заходів. Недотримання ветеринарносанітарних заходів спричиняє поширення інфекційних хвороб серед свинопоголів'я.

Недотримання правил використання антибіотиків для лікування тварин призводить до формування резистентних форм мікроорганізмів. Тому введення у схеми лікування засобів, які одночасно мають полівекторну дію та стимулюють роботу систем організму (а так працює гомеопатія), дозволяє швидко досягти позитивного лікувального ефекту. Так, Радомська Н.А. із Бельовською Р.Г. (2017) пишуть, що гомеопатія $є$ ефективною, нешкідливою і дешевою групою лікарських засобів. Вона дає ресурс організму для кращого і легшого відновлення після будь-яких пошкоджуючих факторів. Окрім того Doehring C., Sundrum A. (2016) стверджують, що вивчення достовірності зменшення чи заміщення антибіотиків у лікуванні продуктивних тварин, із використанням гомеопатичних засобів, можливе лише у рандомізованих контрольованих дослідженнях (Doehring \& Sundrum, 2016).

Doehring C., Sundrum A. у своїй статті “Эфективность гомеопатии у домашнего скота в соответствии с рецензируемыми публикациями с 1981 по 2014 год” повідомляють, що із 48 опублікованих результатів досліджень 26 мали позитивний лікувальний ефект, а у 22 - авторами зареєстровано його відсутність (Doehring \& Sundrum, 2016). Отже, однозначного твердження про ефективність лікарських засобів цієї групи немає. Хоча деякі автори стверджують, що клінічний досвід лікарів, які використовують гомеопатію, з високою достовірністю підтверджують ефективність лікування (Radomskaia \& Belevskaya, 2017).

У ветеринарній медицині також наявні опубліковані результати досліджень вивчення дієвості гомео- патії. При цьому препарати були із різним складом. Так, за використання Silicea terra досягнуто повного одужання коня із рваною раною передньої кінцівки 3 ознаками лихоманки, депресивного стану та нагноєння на фоні неефективної антибіотикотерапії. Важкий стан тварини був обумовлений розмноженням у рані Staphylococcus haemolyticusi Equinobacillus equuli, які були резистентними до гентаміцину, пеніциліну та оксациліну (Weiermayer, 2018). Крім того, про доцільність використання гомеопатії за хронічних хвороб коней у Великобританії повідомляють інші автори (Mathie et al., 2010).

За даними Camerlinк I. end al. використання гомеопатичного засобу "Нозод” (виготовленого із суміші декількох штамів Е. coli) щоденно новонародженим поросятам, а свиноматкам перед опоросом (протягом останнього місяця супоросності двічі на тиждень), сприяло зменшенню в 6 разів випадків проносів у поросят протягом перших 5 діб життя на свинофермі, де загибель молодняку була обумовлена в переважній кількості діареєю (Camerlink et al., 2010).

Також науковими дослідженнями підтверджено забезпечення 50\% профілактичної ефективності діареї у новонароджених ягнят та телят за перорального використання гомеопатичного препарату Dia 100 (Fortuoso et al., 2018). Це комплексний препарат у лікарській формі гелю, який включає Colibacillinum 30C, Mercuriusdulcis 30C, Chinchonaofficinalis 30C, Enterococcinum 200C, Podophylumpeltatum 30C, Colocynthis 30C (Fortuoso et al., 2018).

На ринку ветеринарних препаратів України є досить багато гомеопатичних засобів, які останнім часом включають у схеми лікування здебільшого непродуктивних тварин а саме:

- для лікування розладів травної системи (проносів) - застосовують Веракол, а дискінезії та послабленій функції Ліарсин;

- при захворюваннях нирок - Кантарен, Уролік, Берберисгомокорд;

- як протикашльовий застосовують Лобелон, 
- для стимуляції регенеративних процесів при пошкодженні опорно-рухового апарату - Кафорсен, Азитрофорт,

-для стимуляції імунної системи - Евінтон, Ехінацея композітум, Убіхінонкомпозитум та ін.

Компанії "Heel" i “Вауеr" (Німеччина), "Хелвет" (Росія), Hyland`s (США) є виробниками гомеопатичних препаратів, наявних на ринку нашої країни.

Афлубін $є$ препаратом гомеопатичним, який складається із екстрактів отруйних рослин середнього розведення (AFLUBIN®). В літературі $є$ суперечливі дані щодо доцільності його використання. Тому нам було цікаво з'ясувати клінічний ефект після включення його в схему лікування свиней із респіраторним синдромом, які перебувають на відгодівлі, оскільки ефект плацебо після застосування у тварин не спрацьовує.

Мета - вивчити фармакологічну ефективність афлубіну у схемі лікування свиней із респіраторним синдромом. ня:

Для досягнення мети необхідно розв'язати завдан-

- провести аналіз тривалості відновлення деяких показників гомеостазу без та із використання афлубіну у схемі лікування свиней із респіраторним синдроMOM

- вивчити зміни лейкограми за використання афлубіну.

\section{Матеріал і методи досліджень}

Рандомізовані контрольовані дослідження проведено в умовах приватного господарства Любарського району Житомирської області, в якому утримували свиней.

Зі свиней із респіраторним синдромом за принципом аналогів сформовано три групи по 6 тварин. Для проведення лікування першій групі використовували емульсію амоксиціліну $15 \%$ із розрахунку $1 \mathrm{~cm}^{3} / 10$ кг маси тіла тварини 1 раз на добу протягом 3 діб, другій - цефтріаксон (20 мг/кг маси тіла 2 рази на добу протягом 3-5 діб), третій - разом із цефтріаксоном перорально афлубін із розрахунку 10 крапель $\left(0,5 \mathrm{~cm}^{3}\right)$ на 60 кг маси тіла тварини протягом 3 діб. Свині охоче споживали лікарський засіб, коли ми гомеопатичний препарат набирали у шприц і задавали перорально, вставивши канюлю шприца за нижню губу. Кров для деяких гематологічних досліджень відбирали із вушної вени.

При проведенні роботи були використані клінічні, гематологічні та статистичні методи досліджень. Достовірність зміни температури тіла розраховували за стандартними методиками із використанням комп'ютерної програми Excel.

\section{Результати та їх обговорення}

Відомості щодо дієвості афлубіну в гуманній медицині слугувало підставою для проведення наукових досліджень у ветеринарній медицині. Даний препарат було включено у схему лікування свиней із респіраторним синдромом. В усіх клінічно хворих тварин із сукупністю симптомів ураження дихальної системи реєстрували підвищення температури тіла до 41,0 i $41,1^{\circ} \mathrm{C}$. Результати термометрії хворих свиней приведено в таблиці 1 .

\section{Таблиця 1}

Температура тіла хворих тварин перед проведенням лікування

\begin{tabular}{cccc}
\hline \multirow{2}{*}{ Тварини } & \multicolumn{3}{c}{ Дослідні групи свиней та їх } \\
& температура тіла \\
\cline { 2 - 4 } & 1-ша & 2-га & 3-тя \\
\hline 1 & 41,0 & 41,4 & 40,9 \\
2 & 41,2 & 40,6 & 41,3 \\
3 & 41,3 & 40,9 & 40,6 \\
4 & 40,5 & 41,1 & 41,4 \\
5 & 41,0 & 41,3 & 41,0 \\
6 & 40,8 & 40,7 & 40,8 \\
$\mathrm{M} \pm \mathrm{m}$ & $41,0 \pm 0,12$ & $41,0 \pm 0,13$ & $41,1 \pm 0,12$ \\
\hline
\end{tabular}

Середнє значення температури тіла у тварин усіх груп було майже однаковим, що свідчить, на нашу думку, про однаковий рівень реактивності імунної системи щодо патогенних мікроорганізмів.

При огляді встановили, що свині були кволими, мало рухались, заривались у підстилку, апетит був відсутній. Симптомів розладів травлення, висипів та еритем на шкірі не реєстрували.

Оскільки кількість лейкоцитів та лейкоформула у клінічній практиці інфекційних хвороб свиней має важливе значення і дозволяє визначити частково ступінь реактивності та стан клітинного імунітету, ми провели їх визначення. Результати дослідження наведені в таблиці 2. Отримані результати свідчать про те, що незначне на 4-5\% збільшення лімфоцитів дає можливість припустити, що причиною ураження дихальної системи у свиней господарства $є$ активізація умовно-патогенної мікрофлори. Адже загальновідомо, що лімфоцити - це спеціалізовані клітини, які забезпечують противірусний захист організму. Одночасне зменшення сегментоядерних нейтрофілів на $0,25 \%$ 1,2\% свідчить про активізацію фагоцитозу в організмі тварин. Крім того, у всіх хворих свиней виявлено достовірне зменшення кількості лейкоцитів порівняно 3 показниками групи клінічно здорових, що вказує на зниження рівнів клітинного та гуморального захисту організму. У другій дослідній групі свиней, яким використовували лише цефтріаксон, зареєстровано збільшення лімфоцитів на 7,8\% порівняно з тваринами контрольної групи, які утримувались у господарстві. 
Таблиця 2

Показники лейкоцитів та лейкоформули свиней до лікування

\begin{tabular}{|c|c|c|c|c|c|c|}
\hline \multirow{2}{*}{\multicolumn{2}{|c|}{ Види лейкоцитів, \% }} & \multicolumn{3}{|c|}{ Дослідні групи свиней $(\mathrm{M} \pm \mathrm{m}, \mathrm{n}=6)$} & \multirow{2}{*}{$\begin{array}{c}\text { Клінічно здорові } \\
\text { свині, } \mathrm{n}=6\end{array}$} & \multirow{2}{*}{$\begin{array}{c}\text { Фізіологічні } \\
\text { межі }\end{array}$} \\
\hline & & перша & друга & третя & & \\
\hline Базофіл & & $0,5 \pm 0,05$ & 0 & $0,6 \pm 0,14$ & $0,5 \pm 0,3$ & $0-1$ \\
\hline \multicolumn{2}{|c|}{ Еозинофіли } & $1,5 \pm 0,7$ & $1,5 \pm 0,7$ & $2,3 \pm 0,6$ & $3 \pm 0,4$ & $1-4$ \\
\hline \multirow{3}{*}{ нейтрофіли } & Ю & 0 & 0 & 0 & 0 & 0 \\
\hline & $\Pi$ & $2 \pm 0,4$ & $2,3 \pm 0,1$ & $2,3 \pm 0,3$ & $3,5 \pm 0,4$ & $2-4$ \\
\hline & $\mathrm{C}$ & $39,75 \pm 2,1$ & $40,4 \pm 1,8$ & $38,8 \pm 2,1$ & $44 \pm 1,1$ & $40-48$ \\
\hline \multicolumn{2}{|c|}{ Лімфоцити } & $54 \pm 3,1$ & $53,3 \pm 4,5$ & $54,8 \pm 3,8$ & $46 \pm 0,7$ & $40-50$ \\
\hline \multicolumn{2}{|c|}{ Моноцити } & $2,25 \pm 0,3$ & $2,5 \pm 0,4$ & $2,25 \pm 0,3$ & $3 \pm 0,4$ & $2-6$ \\
\hline \multicolumn{2}{|c|}{ Лейкоцити Г/л } & $6,6 \pm 0,2 *$ & $6,5 \pm 0,3^{*}$ & $6,4 \pm 0,3^{*}$ & $8,8 \pm 0,6$ & $7-12$ \\
\hline
\end{tabular}

Примітка: * $-\mathrm{P} \geq 0,001$ стосовно до свиней клінічно здорових

Отримані дані свідчать про активну імунну відповідь в організмі клінічно хворих свиней на антигени. Оскільки достовірних змін в лейкограмах до та після проведення лікування не було зареєстровано, ми ці показники після клінічного видужання не подаємо. Однак через 5 діб після лікування у другій та третій групі кількість лейкоцитів підвищилась до 7-10 Г/л, тобто стала відповідати рівню клінічно здорових тварин.

Таблиця 3

Результати різних схем лікування
Крім того, з анамнестичних даних відомо, що при закупівлі свиней через 14-21 добу в поросят реєстрували слизові виділення із носових отворів, інтенсивний кашель, апетит був незначно зменшений. Проводилось лікування антибіотиком із групи незахищених пеніцилінів (амоксициліном). Повного одужання не відбувалося. Тому нами було апробовано нові три схеми лікування. Зникнення респіраторних симптомів у свиней після застосування вищевказаних фармакологічних препаратів показано у таблиці 3.

\begin{tabular}{lccc}
\hline \multirow{2}{*}{ Клінічні показники } & \multicolumn{3}{c}{ Відновлення клінічних показників через (годин) } \\
\cline { 2 - 4 } & в першій групі, $\mathrm{n}=6$ & в другій групі, $\mathrm{n}=6$ & в третій групі, $\mathrm{n}=6$ \\
\hline температури тіла ${ }^{\circ} \mathrm{C}$ & $24-48$ & 24 & 12 \\
вживання води & 48 & 24 & $8-10$ \\
наявність апетиту & відсутня & 36 & 12 \\
відсутність виділення із носових ходів & 72 & $48-72$ & $24-36$ \\
\hline
\end{tabular}

3 даних таблиці видно що свиням, яким внутрішньом'язево вводили емульсію амоксициліну 15\% (перша дослідна група), протягом перших 2 діб температура тіла хворих зменшилась до норми. Це вказувало на антибіотикочутливість бактерій, які були складовою етіології патологічного процесу в організмі свиней. Інші симптоми теж зникли, але відновлення апетиту не відбулося, що вказує на неповне відновлення функцій організму. Тому через 3 доби було прийнято рішення щодо введення їм афлубіну (див. матеріали i методи досліджень). Через 12 годин тварини почали поїдали рідку кашу.

У тварин другої дослідної групи, яким вводили розчин цефтріаксону, повне видужання реєстрували через 2 доби. Протягом третьої доби зникли усі симптоми запалення верхніх дихальних шляхів.

У свиней, які одночасно отримували і цефалоспорин, і гомеопатичний засіб афлубін, отримали зниження температури тіла і відновлення апетиту протягом першої доби проведення лікування.

Вважаємо, що позитивний лікувальний ефект досягнуто за складної схеми лікування (третя дослідна група свиней) завдяки діючим речовинам афлубіну. Ймовірно, його складові, стабілізуючи клітинну мембрану різних тканин організму (в т. ч. дихальної), унеможливлюють адсорбцію мікроорганізмів до неї.
Додатково аконіт проявляє противірусну дію і зменшує його кількість в організмі. Ці фактори забезпечують швидкий віруліцидний ефект i, як наслідок, швидке одужання.

Зважаючи, що температура тіла є одним із показників гомеостазу організму, а динаміка її зниження (за різних схем лікування) до фізіологічних меж була різною у часі, ми провели аналіз їі зміни після першої доби застосування препаратів (табл. 4).

\section{Таблиця 4}

Показники температури тіла у тварин після першої доби лікування

\begin{tabular}{cccc}
\hline \multirow{2}{*}{ Тварини } & \multicolumn{3}{c}{ Дослідні групи: } \\
\cline { 2 - 4 } & 1 -ша & 2 -га & 3 -тя \\
\hline 1 & 39,5 & 39,7 & 39,1 \\
2 & 40,1 & 39,8 & 38,8 \\
3 & 40,2 & 38,8 & 39 \\
4 & 39,6 & 39,3 & 39,2 \\
5 & 39,8 & 39,2 & 39,1 \\
6 & 40,1 & 39,6 & 38,9 \\
$\mathrm{M} \pm \mathrm{m}$ & $39,9 \pm 0,11^{*}$ & $39,4 \pm 0,15^{*}$ & $39,0 \pm 0,06^{*}$ \\
\hline
\end{tabular}

Примітки: $*-\mathrm{P} \geq 0,05$ 
Протягом першої доби лікування у тварин, яким вводили емульсію амоксициліну, реєстрували зниження температури тіла до норми лише у 50\%, що вказує на недостатню ефективність лікування.

Встановлено, що фізіологічні показники температури тіла свиней через одну добу проведення лікування цефтріаксоном самостійно та в поєднанні із афлубіном знизилась на $0,5-1,8^{\circ} \mathrm{C}$ порівняно $з$ тваринами, які отримували амоксицилін.

Отримані результати досліджень вказують на доцільність введення афлубіну у схеми лікування свиней 3 респіраторним синдромом. Таке поєднання лікарських засобів позитивно впливає на швидкість відновлення гомеостазу. Крім того, при проведенні терапії свиней усіх 3-х груп дотримувались одного 3 правил хіміотерапії: курс лікування повинен тривати 1-2 доби після клінічного видужання тварини. Дотримання цього правила знижує ризик розвитку рецидиву хвороби.

Отримані результати дають можливість твердити про позитивну фармакологічну дію препарату афлубін разом із цефтріаксоном за прояву респіраторного синдрому у свиней.

Вважаємо, що швидке відновлення клінічних показників гомеостазу за включення до схеми лікування свиней $з$ респіраторним синдромом гомеопатичного засобу афлубін обумовлено його складовими. Даний препарат містить екстракт отруйних рослин Аконіту, Горечавки жовтої, Переступня, які в сукупності у малих дозах мають виражені позитивні впливи на серцево-судинну, дихальну та нервову системи, пришвидшують обмін речовин в клітинах та стабілізують клітинні мембрани. Алкалоїди групи аконітину проявляють противірусну дію, аглікозиди Горечавки жовтої стимулюють роботу травної системи. Зважаючи на результати застосування препарату афлубін у виробничих умовах надаємо детальну характеристику фармакологічної дії лікарської сировини.

Аконіт, або ж борець, (Aconitum L.) - із грецької akoniton перекладається як отруйна рослина. У різних частинах рослини в неоднакових кількостях $(0,18-4 \%)$ наявні алкалоїди групи аконітину: аконітин, мезоаконітин, гіпоаконітин, гепааконітин, сасааконітин, бензоілаконін. Як свідчать результати наукових досліджень (Pogodaeva et al., 2000; Shavel', 2012), малі дози аконіту позитивно діють на організм людини: нормалізують серцевий ритм, дихання, активізують клітинний метаболізм та запобігають розвитку інфекцій, пригнічують ріст новоутворень. Інша складова лікарського засобу є Горечавка жовта, або ж Тирлич жовтий, (Gentianalutea) - рослина, яка містить глікозиди (генціопікрин, амарогентин та декілька гіркихглікозидів: амаросверин, амаропанін, верціамарин). В корені міститься значна кількість генціаніну, який має жарознижуючі та протизапальні властивості, сприяє зменшенню кашлю, судом та дієседативно. Корисні властивості доповнюються і алкалоїдами генціалютин, генціанідин, генціопунктин, генціофлавин (Shavel', 2012; Mihailović et al., 2013).
Застосування галенових препаратів Тирличу жовтого у значних розведеннях поліпшує травлення, збуджує апетит, виявляє жовчогінний ефект, протизапальну і антисептичну активність. У гомеопатії застосовується свіже коріння при відсутності апетиту, зниженні травної функції. В експерименті виявлено гепатопротекторний ефект екстракту надземної частини рослини, який зумовлений вираженою антиоксидантною і мембраностабілізуючою дією (Mihailović et al., 2013).

Бріонія дводомна, або Переступень, (Bryonia) - iï коренева маса містить алкалоїд галегін, глікозиди (бріонін, бріонідин, бріоніцин, бріозид, бріонол), віск, камедь, крохмаль, дубильні речовини, пектин, бріонолову, олеїнову, пальмітинову й інші кислоти, солі яблучної кислоти, цукри, смолу, сечовину, ефірну олію, фітостерини, гіркі речовини - кукурбітацин В, $\mathrm{D}, \mathrm{E}, \mathrm{L}$ та ін. Завдяки цьому Переступень проявляє сечогінну, відхаркувальну, болезаспокійливу, кровоспинну дію, а в невеликих дозах пригнічує центральну нервову систему. Тому 3 давніх часів застосування Бріонії було різноманітним і багатим. Радянська фармакологія рекомендувала витяжки 3 коренів для лікування ревматизму, подагри, невралгії. Гомеопатія пропонує методи лікування трахеїту, бронхіту, плевриту, пневмонії навіть серцевих патологій з допомогою свіжого соку коренів (Shavel', 2012; Vekirchik, 2017).

Характеристика лікарської сировини, яка є складовою гомеопатичного препарату афлубін, зумовлює позитивний лікувальний ефект, який настає в результаті фармакологічної дії лікарських речовин кожної рослини. Це і пояснює швидке відновлення апетиту, зникнення кашлю і виділень із носових ходів. Вважа$€$ щ, що позитивний фармакологічний ефект після включення у схему лікування афлубіну обумовлений фармакологічним синергізмом антибіотика і гомеопатичного препарату.

\section{Висновки}

1. Одночасне застосування свиням із респіраторним синдромом внутрішньом'язево цефтріаксону у дозі 20 мг/кг маси тварини із пероральним введенням препарату афлубін із розрахунку 10 крапель $\left(0,5 \mathrm{~cm}^{3}\right)$ на 60 кг маси тіла забезпечувало клінічне видужання через 12 годин після початку застосування препаратів.

2. Використання цефтріаксону у загальноприйнятих дозах із інтервалом в 12 год, зумовлювало одужання свиней із респіраторним синдромом протягом 48-72 год.

Перспективи подальших досліджень. Препарат афлубін доцільно буде вивчити за комплексного застосування при проведенні вакцинацій у свиноматок та відлучених поросят. 


\section{References}

AFLUBIN®, instrukcija zastosuvannja (UA/1952/02/01). https://medbrowse.com.ua/ua/aflubin-instrukcija. (Nakaz MOZ №85 vid 17.01.2018) (in Ukrainian).

Camerlink, I., Ellinger, L., Bakker, E.J. \& Lantinga, E.A. (2010). Homeopathy as replacement to antibiotics in the case of Escherichia coli diarrhoea in neonatal piglets. Homeopathy, 99(1), 57-62. doi: 10.1016/j.homp.2009.10.003.

Doehring, C., \& Sundrum, A. (2016). Efficacy of homeopathy in livestock according to peer-reviewed publications from 1981 to 2014. Vet Rec., 179(24), 628. doi: 10.1136/vr.103779.

Fortuoso, B.F., Geberta, R.R., Grissa, L.G. et al. (2018). Reduction of stool bacterial counts and prevention of diarrhea using an oral homeopathic product in newborn lambs. Microbial Pathogenesis, 127, 347 351. doi: 10.1016/j.micpath.2018.12.022.

Fortuoso, B.F., Volpato, A., Rampazzo, L., Glombowsky, P., Griss, L.G., Galli, G.M., \& da Silva, A.S. (2018). Homeopathic treatment as an alternative prophylactic to minimize bacterial infection and prevent neonatal diarrhea in calves. Microbial Pathogenesis, 114, 9598. doi: 10.1016/j.micpath.2017.11.04.
Mathie, R.T., Baitson, E.S., Hansen, L., Elliott, M.F., \& Hoare, J. (2010). Homeopathic prescribing for chronic conditions in equine veterinary practice in the UK. Vet Rec., 166(8), 234-238. doi: 10.1136/vr.b4764.

Mihailović, V., Matić, S., Mišić, D. et al. (2013). Chemical composition, antioxidant and antigenotoxic activities of different fractions of Gentiana asclepiadea L. roots extract. EXCLI Journal, 12, 807-823. https://www.ncbi.nlm.nih.gov/pubmed/26622219.

Pogodaeva, N.N., Vereshhagin, A.L., Gorshkov A.G. i dr. (2000). Alkaloidnyj sostav nekotoryh vidov Aconitum L. flory Sibiri. Rast. resursy. 36, 2 (in Russian).

Radomskaia, N.A., \& Belevskaya, R.G. (2017). Homeopathy. Health resources. Russian journal of resources, conservation and recycling, 1(4), 1-11. doi: 10.15862/04RRO117 (in Russian).

Shavel', I. (2012). Tsiliushchi roslyny Ukrainy. Lviv (in Ukrainian).

Vekirchik, K.M. (2017). Otrujni likars'ki roslini. http://toxic-plants.pp.ua/index.php/otrujniroslini/rodyna-zhovtetsevi/330-akonit-dzhungarskij.

Weiermayer, P. (2018). Wound Healing Disorder in a Horse, Associated With Antimicrobial-Resistant Bacteria, Resolved With a Homeopathic Medicine - A Case Report. Journal of Equine Veterinary Science, 67, 37-43. doi: 10.1016/j.jevs.2018.02.027. 